\title{
Hydrogen sulfide generation suppression by nitrate addition - application to solid waste landfill site
}

\author{
Shumpei Kitazaki ${ }^{1}$, Kai Xiao ${ }^{1}$, Kei Nakagawa ${ }^{1}$, Tomonori Kindaichi ${ }^{2}$, Hiroshi Asakura ${ }^{1}{ }^{*}$ \\ ${ }^{1}$ Graduate School of Fisheries Science and Environmental Studies, Nagasaki University, Nagasaki, Japan \\ ${ }^{2}$ Department of Civil and Environmental Engineering, Hiroshima University, Hiroshima, Japan
}

\section{Email address:}

asakura_hiroshi@yahoo.co.jp (H. Asakura)

\section{To cite this article:}

Shumpei Kitazaki, Kai Xiao, Kei Nakagawa, Tomonori Kindaichi, Hiroshi Asakura. Hydrogen Sulfide Generation Suppression by Nitrate Addition - Application to Solid Waste Landfill Site. American Journal of Environmental Protection. Vol. 3, No. 5, 2014 , pp. $267-274$. doi: 10.11648/j.ajep.20140305.20

\begin{abstract}
In Japan, three deaths were reported at an inert solid waste landfill site after exposure to hydrogen sulfide $\left(\mathrm{H}_{2} \mathrm{~S}\right)$ generated at the site. $\mathrm{H}_{2} \mathrm{~S}$ gas is produced when sulfate-reducing bacteria (SRB) convert sulfate derived from waste gypsum board under anaerobic conditions. The recommended countermeasure is to supply oxygen by installing gas venting pipes. However, a large cost is necessary for pipe installation and the pipes are not applicable to coastal landfill sites. On the other hand, $\mathrm{H}_{2} \mathrm{~S}$ generation suppression by nitrate $\left(\mathrm{NO}_{3}\right)$ addition has been reported in sewage systems. In this study, in order to develop a method to suppress $\mathrm{H}_{2} \mathrm{~S}$ generation by $\mathrm{NO}_{3}$ addition at a landfill site, the extent of suppression was quantitatively estimated. When $\mathrm{NO}_{3}$ reagent was added at the rate of 0.46 mmol- $\mathrm{NO}_{3} /(\mathrm{L} \cdot \mathrm{d})$ into a liquid from which $\mathrm{H}_{2} \mathrm{~S}$ gas was generated at the rate of $0.21 \pm 0.05 \mathrm{mmol}-\mathrm{H}_{2} \mathrm{~S} /(\mathrm{L} \cdot \mathrm{d}), \mathrm{H}_{2} \mathrm{~S}$ generation rate was decreased to approximately $1 / 4$ of the original rate. Although it was difficult to maintain the concentration of $\mathrm{NO}_{3}$ because it tended to disappear rapidly, the frequent addition of $\mathrm{NO}_{3}$ reagent to maintain the concentration of approximately $430 \mathrm{mg}-\mathrm{NO}_{3} / \mathrm{L}$ enabled us to control $\mathrm{H}_{2} \mathrm{~S}$ concentration to below 1000 ppmv for one month and $\mathrm{H}_{2} \mathrm{~S}$ generation rate to below $1 / 20$ of the original rate.
\end{abstract}

Keywords: Landfill Site, Waste Gypsum Board, Hydrogen Sulfide, Generation Suppression, Nitrate

\section{Introduction}

A strong offensive smell likened to rotten egg odor is recognizable when hydrogen sulfide $\left(\mathrm{H}_{2} \mathrm{~S}\right)$ gas is present in air at 20-30 ppmv (v: volume) [1]. Inhalation of $\mathrm{H}_{2} \mathrm{~S}$ gas at 750-1000 ppmv causes abrupt physical collapse [2] (hereafter, $\mathrm{H}_{2} \mathrm{~S}$ exceeding 1000 ppmv is called $\mathrm{H}_{2} \mathrm{~S}_{\text {high }}$ ). $\mathrm{H}_{2} \mathrm{~S}$ gas is generated at landfill sites globally [3-8]. In 1999, three workers at an inert solid waste landfill site (a type of landfill site in Japan where waste plastic, rubber, metal, glass, ceramic, and construction and demolition debris (stones, bricks, and blocks) are acceptable, as well as waste gypsum board without protective paper sheet at the time of the accident. No gas venting pipes, liner for leachate, or water treatment facility was available.) died of exposure to 15000 ppmv $\mathrm{H}_{2} \mathrm{~S}$ gas. $\mathrm{H}_{2} \mathrm{~S}$ gas is produced at a landfill when sulfate-reducing bacteria (SRB) consume organic matter and convert sulfate under anaerobic conditions [3, 9, 10]. The source of sulfate in construction and demolition debris is predominantly gypsum $\left(\mathrm{CaSO}_{4}\right)$ [11]. No biodegradable organic matter is acceptable at inert solid waste landfill sites in Japan. Therefore, only waste gypsum board from which protective paper sheet had been removed could be disposed at those landfill sites. Following the report that organic matter in waste gypsum board base material (gypsum part) showed potential for $\mathrm{H}_{2} \mathrm{~S}$ generation [12], the Ministry of the Environment in Japan issued a notice prohibiting the disposal of waste gypsum board at inert solid waste landfill sites in 2006 (Notice: Treatment of waste gypsum board from which protective paper sheet had been removed). Suggested measures for preventing $\mathrm{H}_{2} \mathrm{~S}$ generation or diffusion at a landfill site include the exclusion of anaerobic conditions (water exclusion and/or oxygen supply) [13], trapping of generated $\mathrm{H}_{2} \mathrm{~S}$ gas (conversion into iron sulfide using material containing iron $[14,15]$, and adsorption by activated carbon [16] or zeolite [17]). The Ministry of the Environment in Japan recommended the appropriate installation of cover soil (to prevent rainwater percolation and trap $\mathrm{H}_{2} \mathrm{~S}$ gas 
generated by iron in soil) and the use of gas venting pipes (oxygen supply). However, in regard to the gas venting pipe, a large cost is necessary for installation and the identification of $\mathrm{H}_{2} \mathrm{~S}$ generation spots as the installation points. In addition, oxygen supply to the waste layer via gas venting pipes is impossible at coastal landfill sites because a major portion of the waste layer is found below the surface of inner leachate. Trapping by iron does not prevent $\mathrm{H}_{2} \mathrm{~S}$ generation per se. Therefore, it is necessary to develop a method to suppress $\mathrm{H}_{2} \mathrm{~S}$ generation.

In sewage systems, $\mathrm{H}_{2} \mathrm{~S}$ generation suppression by nitrate $\left(\mathrm{NO}_{3}\right)$ addition has been reported [18, 19]. This was attributed to the increase in oxidation-reduction potential (ORP) caused by the presence of $\mathrm{NO}_{3}$. As Gibbs free energies of oxidation of organic matter $\left(\mathrm{CH}_{2} \mathrm{O}\right)$ with dissolved $\mathrm{O}_{2}$, $\mathrm{NO}_{3}$, and sulfate $\left(\mathrm{SO}_{4}\right)$ as the electron acceptor were -125 , -119 , and $-25.4 \mathrm{~kJ} / \mathrm{mol}$ [20], respectively, the reaction occurred in the order of respiration by aerobic bacteria > denitrification by denitrifying bacteria $>\mathrm{SO}_{4}$ reduction by $\mathrm{SRB}\left(\mathrm{H}_{2} \mathrm{~S}\right.$ generation) [20]. Therefore, if dissolved $\mathrm{O}_{2}$ or $\mathrm{NO}_{3}$ exists, $\mathrm{SO}_{4}$ reduction hardly occurs.

If the $\mathrm{NO}_{3}$ addition method were applicable to the waste layer as well, that method would be a realistic $\mathrm{H}_{2} \mathrm{~S}$ generation suppression method at an actual landfill site. However, no quantitative investigation has been undertaken, such as the determination of the amount of $\mathrm{NO}_{3}$ required to suppress $\mathrm{H}_{2} \mathrm{~S}$ generation. $\mathrm{NO}_{3}$ reagent is used in sewage systems [19]. Compost made from waste organic matter also contains $\mathrm{NO}_{3}$ $[21,22]$. Therefore, if useless $\mathrm{NO}_{3}$ in the market could be used at landfill sites, low cost and effective use of resources would be accomplished.

In this study, in order to develop a method for suppressing $\mathrm{H}_{2} \mathrm{~S}$ generation by $\mathrm{NO}_{3}$ addition at a landfill site, the following parameters were quantitatively estimated.

- Concentration of $\mathrm{NO}_{3}$

- $\mathrm{NO}_{3}$ addition method (intermittent addition and concentration maintenance)

- $\mathrm{NO}_{3}$ type (reagent and compost)

\section{Materials and Methods}

\subsection{Outline of Experiments}

Table 1. Details of samples.

\begin{tabular}{|c|c|c|}
\hline Component & Product name, company & Amount used for a $\mathrm{H}_{2} \mathrm{~S}$ generation bottle \\
\hline & Dried Yeast Extract D-3, Wako Pure Chemical Industries & \\
\hline Organic matter & $\begin{array}{l}\text { Lactose Broth DAIGO, Wako Pure Chemical Industries } \\
\text { (equivalently mixed, and added into pure water) }\end{array}$ & $700 \sim 1000 \mathrm{mg}-\mathrm{C} / \mathrm{L}$ \\
\hline Calcium Sulfate & $\begin{array}{l}\text { Calcium Sulfate }\left(\mathrm{CaSO}_{4} \cdot 2 \mathrm{H}_{2} \mathrm{O}\right) \text {, Japanese Food Additives, Wako Pure Chemical } \\
\text { Industries }\end{array}$ & $25 \mathrm{~g}$ \\
\hline Nutrient & $\begin{array}{l}\text { BOD Nutrient Buffer Pillows for } 6 \mathrm{~L} \text { sample, APHA Formulation, HACH } \\
\text { COMPANY (1 pillow mixed with } 500 \mathrm{~mL} \text { pure water) }\end{array}$ & $25 \mathrm{~mL}$ \\
\hline Seeding & Black sediment in an ornamental pond ( $5 \mathrm{~g}$ mixed with $500 \mathrm{~mL}$ pure water) & $25 \mathrm{~mL}$ \\
\hline Nitrate (reagent) & Sodium Nitrate, 1st grade, Wako Pure Chemical Industries & Depending on the condition \\
\hline Nitrate (compost) & Sewage sludge compost & \\
\hline
\end{tabular}

As only basic experiments were performed in this study, no actual sample, i.e., leachate from landfill site, was used.
In this study, $\mathrm{H}_{2} \mathrm{~S}$ gas was generated in an airtight bottle, and the effect of $\mathrm{H}_{2} \mathrm{~S}$ generation suppression by $\mathrm{NO}_{3}$ addition was evaluated. Specifically, organic matter and $\mathrm{SO}_{4}$ were introduced into the bottle, and an anaerobic condition was preserved. Then, the reproducibility of $\mathrm{H}_{2} \mathrm{~S}_{\text {high }}$ generation was confirmed. $\mathrm{H}_{2} \mathrm{~S}$ in liquid and gas phases was removed by bubbling nitrogen $\left(\mathrm{N}_{2}\right)$ gas, $\mathrm{NO}_{3}$ was added into the bottle, and the duration of $\mathrm{H}_{2} \mathrm{~S}$ generation suppression and the $\mathrm{H}_{2} \mathrm{~S}$ re-generation rate were measured. Sodium nitrate $\left(\mathrm{NaNO}_{3}\right)$ reagent and extract from sewage sludge compost were used as $\mathrm{NO}_{3}$ sources. Two methods of $\mathrm{NO}_{3}$ addition were adopted: intermittent addition and concentration maintenance (Fig. 1).

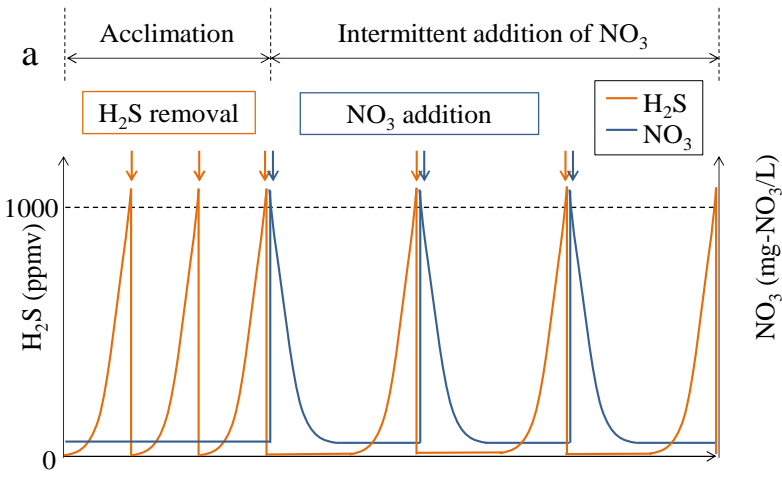

$\mathrm{t}(\mathrm{d})$

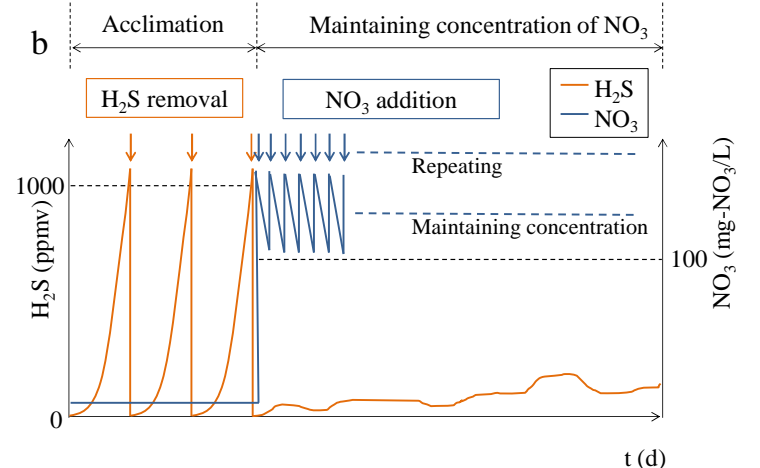

$\mathrm{t}(\mathrm{d})$

Figure 1. Outline of intermittent addition (a) and concentration maintenance (b) test.

\subsection{Materials}

Medium for microbial culture and calcium sulfate $\left(\mathrm{CaSO}_{4} \cdot 2 \mathrm{H}_{2} \mathrm{O}\right)$ were used as organic matter and $\mathrm{SO}_{4}$ sources, 
respectively. $\mathrm{NaNO}_{3}$ reagent and extract from sewage sludge compost were used as $\mathrm{NO}_{3}$ sources. Hereafter, reagent $\mathrm{NO}_{3}$ and $\mathrm{NO}_{3}$ in extract from compost are represented by $\mathrm{N}_{\mathrm{R}}$ and $\mathrm{N}_{\mathrm{C}}$, respectively. Sewage sludge compost and water were mixed at the weight ratio of 1:8 and stirred well, and the supernatant was collected as extract. The concentrations of $\mathrm{NO}_{3}$ and total organic carbon (TOC) in the supernatant were approximately $3500 \mathrm{mg}-\mathrm{NO}_{3} / \mathrm{L}$ and $1900 \mathrm{mg}-\mathrm{C} / \mathrm{L}$, respectively. Details of the samples are shown in Table 1.

\subsection{Experimental Setup}

As shown in Fig. 2, an airtight bottle was made by connecting a gas washing bottle (polycarbonate and polyethylene) to a gas sampling bag (vinylidene fluoride) (called $\mathrm{H}_{2} \mathrm{~S}$ generation bottle hereafter). The gas sampling bag was filled with $\mathrm{N}_{2}$ gas. Samples were introduced into the bottle in the amounts shown in Table 1, and pure water was added to make $350 \mathrm{~mL}$. Total gas volume of head in the bottle and the gas sampling bag was approximately $700 \mathrm{~mL}$.

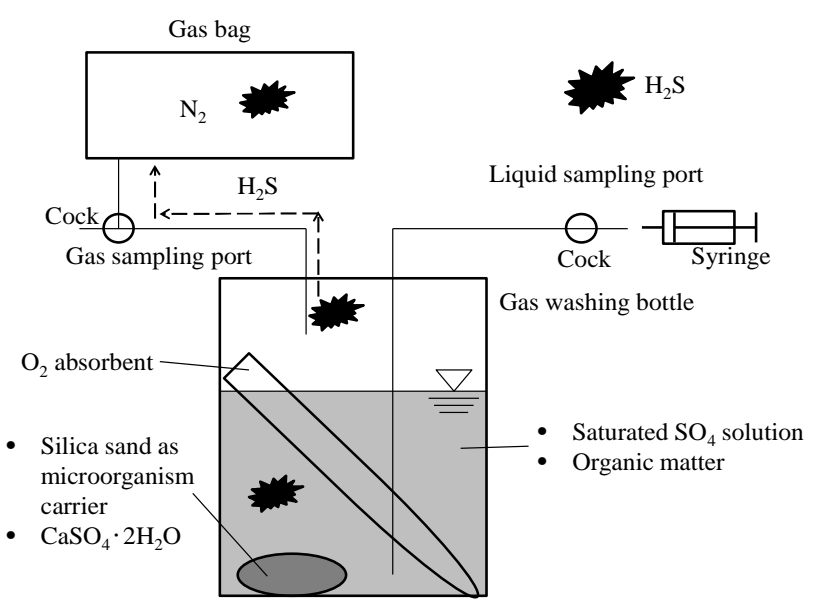

Figure 2. Schematic diagram of $\mathrm{H}_{2} \mathrm{~S}$ generation bottle.

\subsection{Experimental Methods for Acclimation}

The bottle conditions for $\mathrm{H}_{2} \mathrm{~S}_{\text {high }}$ generation were as follows: maintenance of (1) appropriate environment for multiplication of SRB (anaerobic condition, temperature for mesophilic bacterial growth), (2) high concentration of organic matter, and (3) presence of $\mathrm{SO}_{4}$ [12]. To maintain condition (1), oxygen absorbent (tube filled with sodium sulfite solution) was introduced into the $\mathrm{H}_{2} \mathrm{~S}$ generation bottle, and the bottle was set in an incubator $\left(35^{\circ} \mathrm{C}\right)$. To maintain condition (2), TOC in the liquid phase was measured two times a week, organic matter was injected, and
TOC after the injection was re-measured. Thus, TOC was maintained in an amount ranging from 700 to $1000 \mathrm{mg}-\mathrm{C} / \mathrm{L}$. To maintain condition (3), $\mathrm{SO}_{4}$ was introduced into the bottle in an amount equivalent to 30 times that required for the saturation of $\mathrm{CaSO}_{4} \cdot 2 \mathrm{H}_{2} \mathrm{O}$ (approximately $1700 \mathrm{mg}-\mathrm{SO}_{4} / \mathrm{L}$,

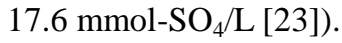

Nine $\mathrm{H}_{2} \mathrm{~S}$ generation bottles (RUNS 1-9) were prepared. $\mathrm{H}_{2} \mathrm{~S}$ in the liquid and gas phases was removed by bubbling $\mathrm{N}_{2}$ gas when $\mathrm{H}_{2} \mathrm{~S}_{\text {high }}$ was observed. $\mathrm{H}_{2} \mathrm{~S}_{\text {high }}$ observation and $\mathrm{H}_{2} \mathrm{~S}$ removal were conducted three times as the acclimation stage, and then, the $\mathrm{H}_{2} \mathrm{~S}$ generation suppression test was performed.

\subsection{Experimental Methods for $\mathrm{H}_{2} \mathrm{~S}$ Generation Suppression}

In the $\mathrm{H}_{2} \mathrm{~S}$ generation suppression test, $\mathrm{NO}_{3}$ was added into the $\mathrm{H}_{2} \mathrm{~S}$ generation bottle after acclimation was completed, and its effect on $\mathrm{H}_{2} \mathrm{~S}$ generation was evaluated. High $(\mathrm{H})$ and low $(\mathrm{L})$ concentrations of $\mathrm{NO}_{3}$ were added, i.e., $7.0 \mathrm{mmol}-\mathrm{NO}_{3} / \mathrm{L}\left(430 \mathrm{mg}-\mathrm{NO}_{3} / \mathrm{L}\right)$ and $1.76 \mathrm{mmol}-\mathrm{NO}_{3} / \mathrm{L}$ (110 mg- $\left.\mathrm{NO}_{3} / \mathrm{L}\right)$, respectively. Those concentrations are 0.4 and 0.1 times the saturation concentration of $\mathrm{SO}_{4}(17.6$ $\left.\mathrm{mmol}-\mathrm{SO}_{4} / \mathrm{L}\right)$.

Although ideally, the experiments should be conducted in individual bottles, because of limited space and budget, the same bottle (as it is, no changes of content) was used repeatedly for the experiments. After the intermittent addition test (I), the concentration maintenance test (M) was conducted in RUNS 1-6. Control experiments (no $\mathrm{NO}_{3}$ addition) were performed in RUNS 7-9.

The procedures and the end conditions for each experiment are as follows. In the intermittent addition test, $\mathrm{HN}_{\mathrm{R}}, \mathrm{LN}_{\mathrm{R}}$ or $\mathrm{HN}_{\mathrm{C}}$ was added into the bottle and conditions (1)-(3) were maintained. When the $\mathrm{H}_{2} \mathrm{~S}$ generation suppression effect of $\mathrm{NO}_{3}$ disappeared and $\mathrm{H}_{2} \mathrm{~S}_{\text {high }}$ was observed, $\mathrm{H}_{2} \mathrm{~S}$ was removed by bubbling $\mathrm{N}_{2}$ gas, and $\mathrm{NO}_{3}$ was added again. The experiment was terminated after observing $\mathrm{H}_{2} \mathrm{~S}_{\text {high }}$ six times. In the concentration maintenance test, conditions (1)-(3) were maintained, and $\mathrm{HN}_{\mathrm{R}}$ or $\mathrm{HN}_{\mathrm{C}}$ was added into the bottle to maintain $\mathrm{NO}_{3}$ concentration from 100 to $430 \mathrm{mg}-\mathrm{NO}_{3} / \mathrm{L}$. The experiment was terminated when $\mathrm{H}_{2} \mathrm{~S}$ concentration could be controlled to below 1000 ppmv for one month.

The experimental conditions and procedures are shown in Table 2. The abbreviations of the experiments are also listed in Table 2. For example, the abbreviation for high concentration $(\mathrm{H})$, reagent $\mathrm{NO}_{3}\left(\mathrm{~N}_{\mathrm{R}}\right)$, and intermittent addition test (I) is $\mathrm{HN}_{\mathrm{R}} \mathrm{I}$.

Table 2. Experimental conditions and procedures.

\begin{tabular}{|c|c|c|c|c|c|}
\hline Experiment type & $\begin{array}{l}\text { Abbre } \\
\text { viation }\end{array}$ & Procedure & $\begin{array}{l}\mathrm{NO}_{3} \text { addition } \\
\left(\mathrm{mg}-\mathrm{NO}_{3} / \mathrm{L}\right)\end{array}$ & End condition & RUN No. \\
\hline Acclimation & & $*-\mathrm{H}_{2} \mathrm{~S}_{\text {high }}$ generation- $\mathrm{H}_{2} \mathrm{~S}$ removal-back to $*$ & 0 & $\begin{array}{l}3 \text { times of } \mathrm{H}_{2} \mathrm{~S}_{\text {high }} \\
\text { generation }\end{array}$ & $1-9$ \\
\hline $\begin{array}{l}\text { High conc. nitrate (reagent) } \\
\text { intermittent addition }\end{array}$ & $\mathrm{HN}_{\mathrm{R}} \mathrm{I}$ & $\begin{array}{l}*-\mathrm{H}_{2} \mathrm{~S}_{\text {high }} \text { generation- }-\mathrm{H}_{2} \mathrm{~S} \text { removal }-\mathrm{HN}_{\mathrm{R}} \\
\text { addition-back to } *\end{array}$ & 430 & $\begin{array}{l}6 \text { times of } \mathrm{H}_{2} \mathrm{~S}_{\text {high }} \\
\text { generation }\end{array}$ & $1,2,3$ \\
\hline $\begin{array}{l}\text { Low conc. nitrate (reagent) } \\
\text { intermittent addition }\end{array}$ & $\mathrm{LN}_{\mathrm{R}} \mathrm{I}$ & $\begin{array}{l}*-\mathrm{H}_{2} \mathrm{~S}_{\text {high }} \text { generation- } \mathrm{H}_{2} \mathrm{~S} \text { removal }-\mathrm{LN}_{\mathrm{R}} \\
\text { addition-back to } *\end{array}$ & 110 & $\begin{array}{l}6 \text { times of } \mathrm{H}_{2} \mathrm{~S}_{\text {high }} \\
\text { generation }\end{array}$ & $4,5,6$ \\
\hline
\end{tabular}




\begin{tabular}{|c|c|c|c|c|c|}
\hline Experiment type & $\begin{array}{l}\text { Abbre } \\
\text { viation }\end{array}$ & Procedure & $\begin{array}{l}\mathrm{NO}_{3} \text { addition } \\
\left(\mathrm{mg}-\mathrm{NO}_{3} / \mathrm{L}\right)\end{array}$ & End condition & RUN No. \\
\hline $\begin{array}{l}\text { High conc. nitrate (compost) } \\
\text { intermittent addition }\end{array}$ & $\mathrm{HN}_{\mathrm{C}} \mathrm{I}$ & $\begin{array}{l}*-\mathrm{H}_{2} \mathrm{~S}_{\text {high }} \text { generation- }-\mathrm{H}_{2} \mathrm{~S} \text { removal }-\mathrm{HN}_{\mathrm{C}} \\
\text { addition—back to } *\end{array}$ & 430 & $\begin{array}{l}6 \text { times of } \mathrm{H}_{2} \mathrm{~S}_{\text {high }} \\
\text { generation }\end{array}$ & $4,5,6$ \\
\hline $\begin{array}{l}\text { High conc. nitrate (reagent) } \\
\text { maintenance }\end{array}$ & $\mathrm{HN}_{\mathrm{R}} \mathrm{M}$ & $\begin{array}{l}*-<\mathrm{NO}_{3} 100 \mathrm{mg}-\mathrm{NO}_{3} / \mathrm{L}-\mathrm{HN}_{\mathrm{R}} \text { addition-back } \\
\text { to } *\end{array}$ & 430 & $\begin{array}{l}\text { Maintaining }<1000 \\
\text { ppmv } \mathrm{H}_{2} \mathrm{~S} \text { for one month }\end{array}$ & $1,2,3$ \\
\hline $\begin{array}{l}\text { High conc. nitrate (compost) } \\
\text { maintenance }\end{array}$ & $\mathrm{HN}_{\mathrm{C}} \mathrm{M}$ & $\begin{array}{l}* \text { —— } \mathrm{NO}_{3} 100 \mathrm{mg}-\mathrm{NO}_{3} / \mathrm{L}-\mathrm{HN}_{\mathrm{C}} \text { addition-back } \\
\text { to } *\end{array}$ & 430 & $\begin{array}{l}\text { Maintaining }<1000 \\
\text { ppmv } \mathrm{H}_{2} \mathrm{~S} \text { for one month }\end{array}$ & $1,2,4$ \\
\hline Control & & $*-\mathrm{H}_{2} \mathrm{~S}_{\text {high }}$ generation $-\mathrm{H}_{2} \mathrm{~S}$ removal - back to $*$ & 0 & - & $7,8,9$ \\
\hline
\end{tabular}

\subsection{Analytical Procedure}

The objects of measurement were the gas and liquid phases in the $\mathrm{H}_{2} \mathrm{~S}$ generation bottle. Measurement items for the gas phase were $\mathrm{H}_{2} \mathrm{~S}$ concentration and gas volume. Measurement items for the liquid phase were $\mathrm{pH}$, electric conductivity (EC), ORP, TOC, $\mathrm{NO}_{3}$ concentration, and liquid volume.

In regard to the gas phase, $\mathrm{H}_{2} \mathrm{~S}$ was measured with a portable gas detector for worker safety (XS-2200, controlled potential electrolysis, NEW COSMOS ELECTRIC CO., LTD.). Gas volume in the gas bag was measured by reading the scale on a plastic syringe used to withdraw the gas from the bag. Then, the gas bag was newly filled with $\mathrm{N}_{2}$ gas and reconnected to the bottle.

In regard to the liquid phase, HORIBA B-212 (pH), HORIBA B-173 (EC), HORIBA-D-55 and 9300-10D (ORP), Shimadzu TOC- $\mathrm{V}_{\mathrm{WS}}$ (TOC), and HORIBA B-343 $\left(\mathrm{NO}_{3}\right)$ were used. Liquid volume was estimated by measuring the gross weight of the $\mathrm{H}_{2} \mathrm{~S}$ generation bottle. Liquid $(10 \mathrm{~mL})$ was sampled from the liquid sampling port (Fig. 2) with a plastic syringe. Liquid volume in the $\mathrm{H}_{2} \mathrm{~S}$ generation bottle was maintained by adding $10 \mathrm{~mL}$ solution containing organic matter or $\mathrm{NO}_{3}$.

$\mathrm{H}_{2} \mathrm{~S}$, gas volume, $\mathrm{pH}, \mathrm{EC}$, ORP, and $\mathrm{NO}_{3}$ concentration were measured four times a week, and TOC was measured two times a week. In addition, TOC was re-measured immediately after adding organic matter.

\section{Results}

Changes in the concentrations of $\mathrm{H}_{2} \mathrm{~S}$ and $\mathrm{NO}_{3}$, and the ORP in RUNS 1, 4, and 7 are shown in Fig. 3, 4, and 5, respectively. The results of RUNS 2, 3, 5, 6, 8, and 9 are omitted. The $\mathrm{pH}$ ranged from 5.9 to 8.8 , was increased with time, and was around 8 after 30 days. EC ranged from 3.2 to $11.9 \mathrm{mS} / \mathrm{cm}$ and was increased with time upon the addition of $\mathrm{NO}_{3}$.

\subsection{Intermittent Addition Test}

ORP in $\mathrm{HN}_{\mathrm{R}} \mathrm{I}$ was increased upon the addition of $\mathrm{NO}_{3}$. On the other hand, ORP in $\mathrm{LN}_{\mathrm{R}} \mathrm{I}$ and $\mathrm{HN}_{\mathrm{C}} \mathrm{I}$ did not show a constant increase. $\mathrm{H}_{2} \mathrm{~S}_{\text {high }}$ was generated when ORP was below $-100 \mathrm{mV}$ (standard hydrogen electrode). Regarding $\mathrm{HN}_{\mathrm{R}} \mathrm{I}$ and $\mathrm{HN}_{\mathrm{C}} \mathrm{I}$, there were cases that $\mathrm{NO}_{3}$ concentration was decreased to below the detection limit $\left(50 \mathrm{mg}-\mathrm{NO}_{3} / \mathrm{L}\right)$ on the next measurement day, i.e., after two days. Therefore, $\mathrm{NO}_{3}$ might have disappeared in two days.

\subsection{Concentration Maintenance Test}

Because of the rapid disappearance of $\mathrm{NO}_{3}$ in $\mathrm{HN}_{\mathrm{R}} \mathrm{M}, \mathrm{NO}_{3}$ reagent had to be added frequently. $\mathrm{NO}_{3}$ concentration could not be maintained at an exact value because it was below the detection limit when $\mathrm{NO}_{3}$ reagent was added. ORP was increased and exceeded $100 \mathrm{mV}$ with the repeated addition of $\mathrm{NO}_{3}$ reagent. $\mathrm{H}_{2} \mathrm{~S}_{\text {high }}$ was not generated for one month, i.e., the target time. Although $\mathrm{NO}_{3}$ concentration was decreased slowly and $\mathrm{NO}_{3}$ was added only two times in $\mathrm{HN}_{\mathrm{C}} \mathrm{M}, \mathrm{H}_{2} \mathrm{~S}_{\text {high }}$ was not generated for one month. ORP was below $-100 \mathrm{mV}$.

\subsection{Control}

ORP was below $-100 \mathrm{mV}$ after 10 days and $\mathrm{H}_{2} \mathrm{~S}_{\text {high }}$ was generated repeatedly in control (Fig. 5). ORP exhibited both increases and decreases, and no obvious tendency was observed. The regeneration of $\mathrm{H}_{2} \mathrm{~S}$ immediately after $\mathrm{H}_{2} \mathrm{~S}$ removal by bubbling $\mathrm{N}_{2}$ gas was slower than that immediately before removal. $\mathrm{NO}_{3}$ concentration was near the detection limit.

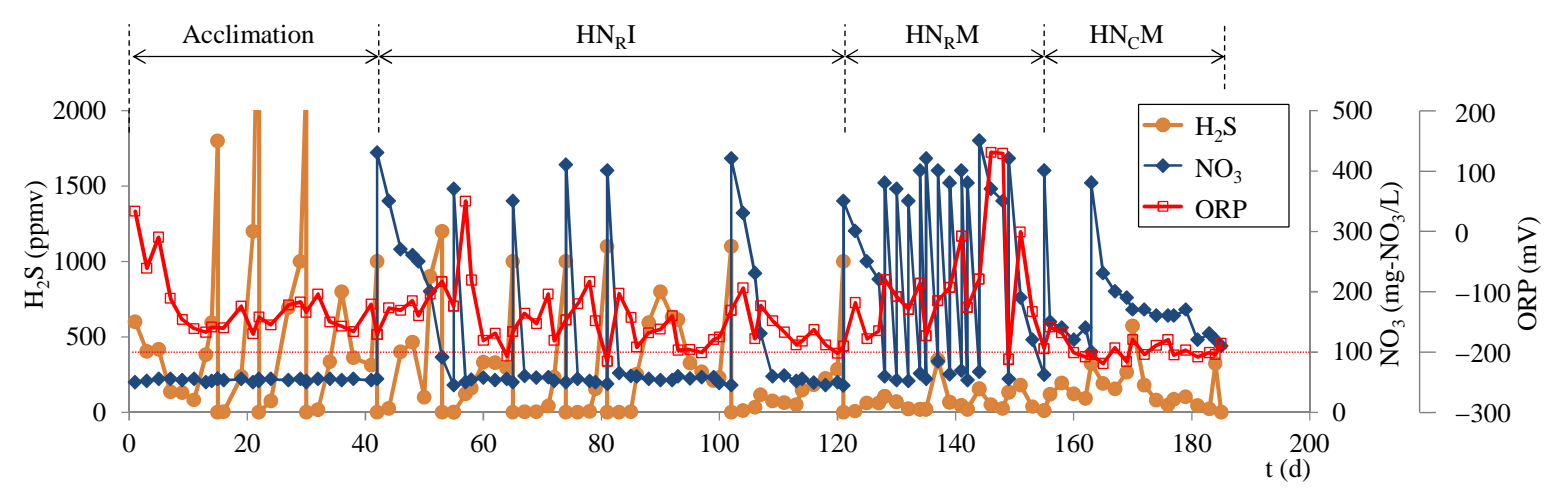

Figure 3. Concentration changes in RUN 1. 


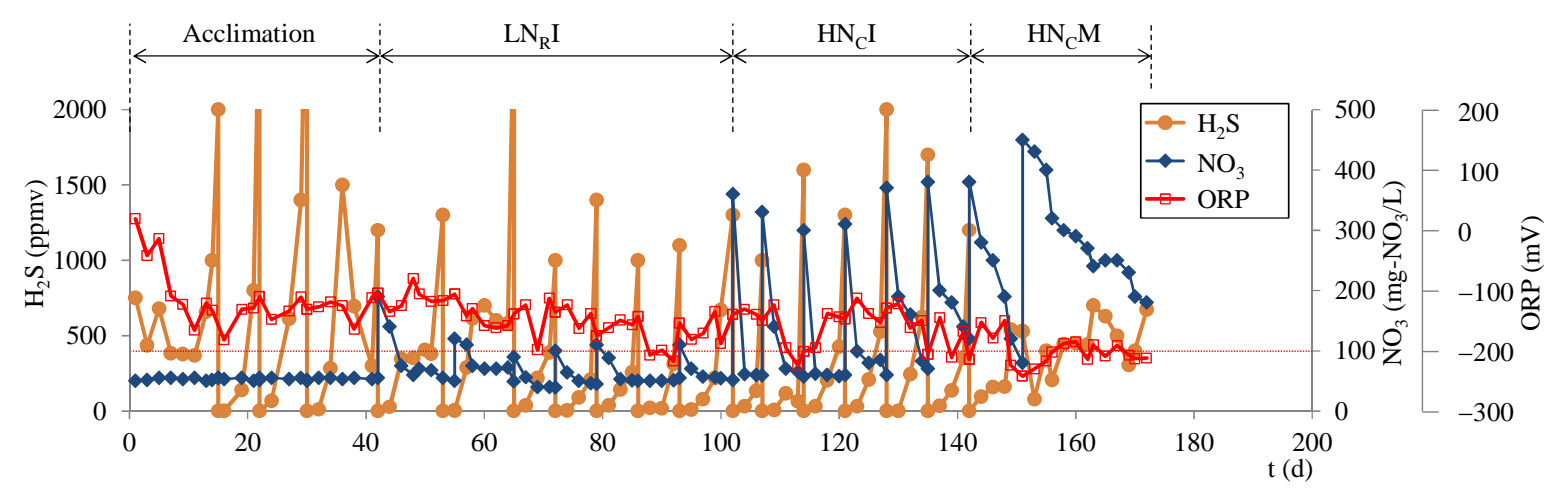

Figure 4. Concentration changes in RUN 4.

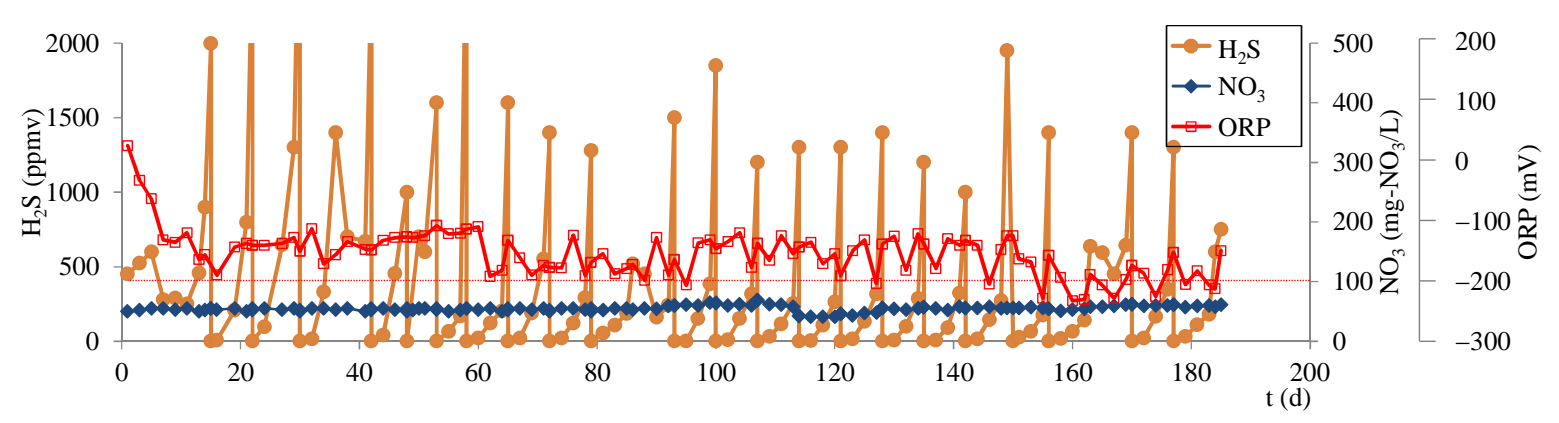

Figure 5. Concentration changes in RUN 7 (control).

\section{Discussion}

\subsection{Quantitative Evaluation of $\mathrm{H}_{2} \mathrm{~S}$ Generation Suppression by $\mathrm{NO}_{3}$ Addition}

The effect of $\mathrm{NO}_{3}$ addition on $\mathrm{H}_{2} \mathrm{~S}$ generation suppression was quantitatively estimated as follows. The number of days required for exceeding $1000 \mathrm{ppmv} \mathrm{H}_{2} \mathrm{~S}$ is shown in Fig. 6. In control, $7.6 \pm 2.1$ days (average \pm standard deviation) were required for exceeding $1000 \mathrm{ppmv} \mathrm{H}_{2} \mathrm{~S}$. The required number of days in $\mathrm{LN}_{\mathrm{R}} \mathrm{I}$ and $\mathrm{HN}_{\mathrm{C}} \mathrm{I}$ was almost the same as that in control. On the other hand, in the case of $\mathrm{HN}_{\mathrm{R}} \mathrm{I}, 15.2 \pm 8.2$ days were required, i.e., twice that of control in spite of the large variance. $\mathrm{H}_{2} \mathrm{~S}_{\text {high }}$ was not generated in $\mathrm{HN}_{\mathrm{R}} \mathrm{M}$ and $\mathrm{HN}_{\mathrm{C}} \mathrm{M}$ for one month.

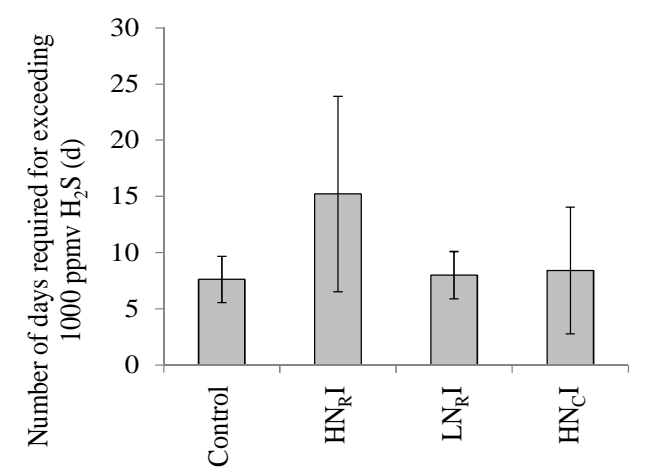

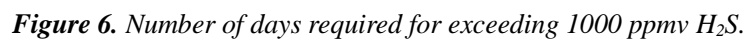

$\mathrm{H}_{2} \mathrm{~S}$ generation rates are shown in Fig. 7. Generation rate was determined from the increase of $\mathrm{H}_{2} \mathrm{~S}$ concentration per unit time from the day of $\mathrm{H}_{2} \mathrm{~S}$ removal by bubbling $\mathrm{N}_{2}$ gas to the day $\mathrm{H}_{2} \mathrm{~S}$ exceeded 1000 ppmv (However, two days were used for the concentration maintenance test). It is known that $\mathrm{H}_{2} \mathrm{~S}$ exists in not only the gas phase but also the liquid phase. Using the concentration in the gas phase, gas volume, liquid volume, and $\mathrm{pH}$, concentration in the liquid phase was calculated according to Henry's law and an equilibrium relationship in the liquid phase [24]. As $\mathrm{H}_{2} \mathrm{~S}$ was generated from the liquid phase, the generation rate was converted into the rate per unit liquid volume $\left(m m o l-\mathrm{H}_{2} \mathrm{~S} /(\mathrm{L} \cdot \mathrm{d})\right)$. The generation rate in control was $0.21 \pm 0.05 \mathrm{mmol}-\mathrm{H}_{2} \mathrm{~S} /(\mathrm{L} \cdot \mathrm{d})$. The rates in $\mathrm{LN}_{\mathrm{R}} \mathrm{I}$ and $\mathrm{HN}_{\mathrm{C}} \mathrm{I}$ were the same as that in control. On the other hand, the rate in $\mathrm{HN}_{\mathrm{R}} \mathrm{I}$ was $0.051 \pm 0.024$ mmol- $\mathrm{H}_{2} \mathrm{~S} /(\mathrm{L} \cdot \mathrm{d})$, i.e., approximately $1 / 4$ of control. In spite of the disappearance of $\mathrm{NO}_{3}, \mathrm{H}_{2} \mathrm{~S}$ was not generated immediately, i.e., the generation was suppressed from 60 to 80 days. The reason for the lack of decrease of the generation rate in $\mathrm{HN}_{\mathrm{C}} \mathrm{I}$ is unknown. The rates in the concentration maintenance test $\left(\mathrm{HN}_{\mathrm{R}} \mathrm{M}\right.$ and $\left.\mathrm{HN}_{\mathrm{C}} \mathrm{M}\right)$ were below $1 / 20$ of control. However, $\mathrm{NO}_{3}$ concentration could not be maintained because of its rapid disappearance in $\mathrm{HN}_{\mathrm{R}} \mathrm{M}$.

$\mathrm{NO}_{3}$ addition rates are shown in Fig. 8. The rates in $\mathrm{HN}_{\mathrm{R}} \mathrm{I}$, $\mathrm{LN}_{\mathrm{R}} \mathrm{I}, \quad \mathrm{HN}_{\mathrm{C}} \mathrm{I}$, and $\mathrm{HN}_{\mathrm{C}} \mathrm{M}$ ranged from 0.20 to 0.71 mmol- $\mathrm{NO}_{3} /(\mathrm{L} \cdot \mathrm{d})$, whereas that in $\mathrm{HN}_{\mathrm{R}} \mathrm{M}$ was more than 3-fold, i.e., $2.2 \mathrm{mmol}-\mathrm{NO}_{3} /(\mathrm{L} \cdot \mathrm{d})$. This is because the experimental conditions required that $\mathrm{NO}_{3}$ concentration be maintained at 100 to $430 \mathrm{mg}-\mathrm{NO}_{3} / \mathrm{L}$, i.e., it was not our purpose to determine the minimum concentration of $\mathrm{NO}_{3}$ required to suppress $\mathrm{H}_{2} \mathrm{~S}_{\text {high }}$ generation. In addition, $\mathrm{NO}_{3}$ disappeared rapidly. Therefore, it is possible to suppress 
$\mathrm{H}_{2} \mathrm{~S}_{\text {high }}$ generation even if the $\mathrm{NO}_{3}$ addition rate is below 2.2 mmol- $\mathrm{NO}_{3} /(\mathrm{L} \cdot \mathrm{d})$. For example, if $\mathrm{HN}_{\mathrm{R}} \mathrm{I}$ was regarded as having $\mathrm{H}_{2} \mathrm{~S}$ generation suppression effect because of the decreased $\mathrm{H}_{2} \mathrm{~S}$ generation rate, $\mathrm{H}_{2} \mathrm{~S}_{\text {high }}$ generation was possibly suppressed by the above $\mathrm{NO}_{3}$ addition rate of 0.46 mmol- $\mathrm{NO}_{3} /(\mathrm{L} \cdot \mathrm{d})$ in $\mathrm{HN}_{\mathrm{R}} \mathrm{I}$.

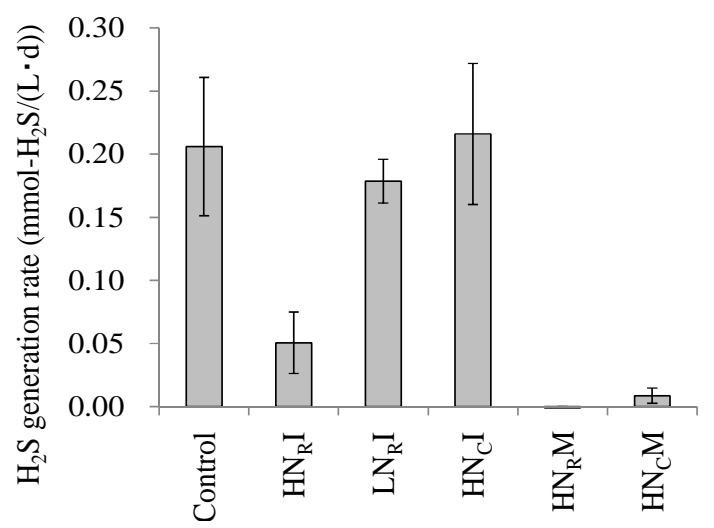

Figure 7. $\mathrm{H}_{2} \mathrm{~S}$ generation rates.

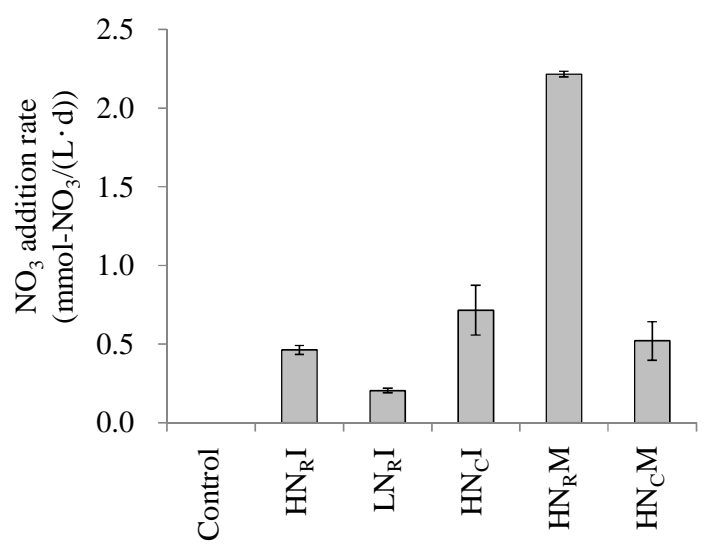

Figure 8. $\mathrm{NO}_{3}$ addition rates.

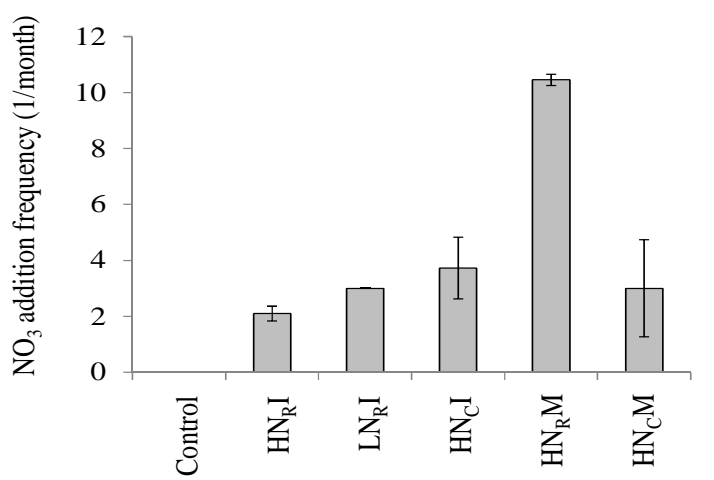

Figure 9. $\mathrm{NO}_{3}$ addition frequencies.

$\mathrm{NO}_{3}$ addition frequencies are shown in Fig. 9. The frequencies in $\mathrm{HN}_{\mathrm{R}} \mathrm{I}, \mathrm{LN}_{\mathrm{R}} \mathrm{I}, \mathrm{HN}_{\mathrm{C}} \mathrm{I}$, and $\mathrm{HN}_{\mathrm{C}} \mathrm{M}$ ranged from 2.1 to 3.71 /month, whereas that in $\mathrm{HN}_{\mathrm{R}} \mathrm{M}$ was more than twice those values, i.e., $10.51 /$ month. The reason is the same as that for the $\mathrm{NO}_{3}$ addition rate.

The following is a summary of the above results. By adding $\mathrm{NO}_{3}$ reagent at the rate of $0.46 \mathrm{mmol}-\mathrm{NO}_{3} /(\mathrm{L} \cdot \mathrm{d})$ into a liquid from which $\mathrm{H}_{2} \mathrm{~S}$ gas was generated at the rate of 0.21 $\pm 0.05 \mathrm{mmol}-\mathrm{H}_{2} \mathrm{~S} /(\mathrm{L} \cdot \mathrm{d}), \mathrm{H}_{2} \mathrm{~S}$ generation rate was decreased to approximately $1 / 4$ of the original rate. Although it was difficult to maintain the concentration of $\mathrm{NO}_{3}$ because of its rapid disappearance, by frequently adding $\mathrm{NO}_{3}$ reagent to maintain a concentration of approximately $430 \mathrm{mg}-\mathrm{NO}_{3} / \mathrm{L}$, $\mathrm{H}_{2} \mathrm{~S}$ concentration could be controlled to below $1000 \mathrm{ppmv}$ for one month, and $\mathrm{H}_{2} \mathrm{~S}$ generation rate was below $1 / 20$ of the original rate.

\subsection{Problems Encountered, Application of Results, and Future Issues}

Regarding the addition of $\mathrm{NO}_{3}$ derived from compost, it was assumed that the frequent addition of $\mathrm{NO}_{3}$ in $\mathrm{HN}_{\mathrm{C}} \mathrm{M}$ was required because of the rapid disappearance of $\mathrm{NO}_{3}$, in the same manner as that in $\mathrm{HN}_{\mathrm{R}} \mathrm{M}$. However, the results (Fig. 3) indicated that the decrease of $\mathrm{NO}_{3}$ concentration was slow in $\mathrm{HN}_{\mathrm{C}} \mathrm{M}$, and $\mathrm{H}_{2} \mathrm{~S}_{\text {high }}$ generation was suppressed by the addition of $\mathrm{NO}_{3}$ in small amounts. In addition, the disappearance of $\mathrm{NO}_{3}$ proceeded more slowly in $\mathrm{HN}_{\mathrm{C}} \mathrm{M}$ than in $\mathrm{HN}_{\mathrm{C}} \mathrm{I}$ in spite of use of the same $\mathrm{NO}_{3}$ derived from compost (Fig. 4). The internal environment might have been changed because some experiments were continuously conducted in the same bottle after another experiment was completed. Compost contains stable organic matter, such as humic substances [25]. A larger amount of stable organic matter was contained in compost made from sewage sludge than in compost made from food waste [26]. The hydrophobic domains in humic substances prevent microbial activity associated with water [27]. In this study, medium for microbial culture was added as organic matter to maintain TOC at 700-1000 mg-C/L. However, when extract from compost was used for $\mathrm{NO}_{3}$ addition, humic substances contained in compost would be included as well. As humic substances are also organic matter, they would increase TOC in the bottle and consequently decrease the amount of organic matter derived from medium for microbial culture. Thus, the authors speculate that $\mathrm{H}_{2} \mathrm{~S}$ generation potential was decreased in $\mathrm{HN}_{\mathrm{C}} \mathrm{M}$ because TOC derived from humic substances, which are stable organic matter, was increased and consequently, the net amount of TOC available to SRB was decreased. This result led to two suggestions: the $\mathrm{H}_{2} \mathrm{~S}$ generation suppression effect in $\mathrm{HN}_{\mathrm{C}} \mathrm{M}$ was overestimated, and $\mathrm{H}_{2} \mathrm{~S}$ generation potential did not increase in spite of the increase of TOC due to humic substances contained in compost (availability of use at an actual landfill site).

The amount of $\mathrm{NO}_{3}$ to be added to a waste layer of a landfill site where $\mathrm{H}_{2} \mathrm{~S}$ is generated can be estimated from the results obtained in this study. Future issues are as follows. In regard to the experiment using $\mathrm{NO}_{3}$ derived from compost, additional experiments are required with control of the net amount of organic matter. Environmental loading, such as eutrophication by application of the $\mathrm{NO}_{3}$ addition method at a pilot scale or an actual landfill site, and cost reduction by using useless $\mathrm{NO}_{3}$ in the market should be evaluated. $\mathrm{As} \mathrm{NO}_{3}$ addition is an alternative method for supplying oxygen, its advantages should be evaluated quantitatively. The advantages include no consumption of large amounts of $\mathrm{NO}_{3}$ 
in the aerobic zone and consumption of organic matter by denitrification. Specifically, the decomposition of organic matter has to rely on anaerobic decomposition because oxygen supply via gas venting pipes to the waste layer at a coastal landfill site, which has a large amount of retained inner leachate, is not feasible. If both $\mathrm{H}_{2} \mathrm{~S}$ generation suppression and the consumption of large amounts of organic matter by denitrification could be realized, stabilization of waste layer at landfill site would be accelerated.

\section{Conclusion}

In this study, in order to develop a method to suppress $\mathrm{H}_{2} \mathrm{~S}$ generation by $\mathrm{NO}_{3}$ addition at a landfill site, the extent of suppression was quantitatively estimated. When $\mathrm{NO}_{3}$ reagent was added at the rate of $0.46 \mathrm{mmol}-\mathrm{NO}_{3} /(\mathrm{L} \cdot \mathrm{d})$ into a liquid from which $\mathrm{H}_{2} \mathrm{~S}$ gas was generated at the rate of $0.21 \pm 0.05$ mmol- $\mathrm{H}_{2} \mathrm{~S} /(\mathrm{L} \cdot \mathrm{d}), \mathrm{H}_{2} \mathrm{~S}$ generation rate was decreased to approximately $1 / 4$ of the original rate. Although it was difficult to maintain the concentration of $\mathrm{NO}_{3}$ because of its rapid disappearance, by frequently adding $\mathrm{NO}_{3}$ to maintain a concentration of approximately $430 \quad \mathrm{mg}-\mathrm{NO}_{3} / \mathrm{L}$, the concentration of $\mathrm{H}_{2} \mathrm{~S}$ would be controlled to below 1000 ppmv for one month and $\mathrm{H}_{2} \mathrm{~S}$ generation rate would be reduced to below $1 / 20$ of the original rate. The disappearance of $\mathrm{NO}_{3}$ derived from compost was slow and $\mathrm{H}_{2} \mathrm{~S}$ generation was suppressed by the addition of a small amount of $\mathrm{NO}_{3}$. Additional experiments are required as the net amount of organic matter for SRB could not be controlled.

\section{Acknowledgements}

This research was supported by a Grant-in-Aid for Young Scientists B (25740039) from Japan Society for the Promotion of Science (JSPS).

\section{References}

[1] Reiffenstein, R.J., Hulbert, W.C., Roth, S.H., 1992. Toxicology of Hydrogen Sulfide. Annual Review of Pharmacology and Toxicology 32, 109-134.

[2] Milby, T.H., Baselt, R.C., 1999. Hydrogen Sulfide Poisoning: Clarification of Some Controversial Issues. American Journal of Industrial Medicine 35, 192-195.

[3] Lee, S., Xu, Q., Booth, M., Townsend, T.G., Chadik, P., Bitton, G., 2006. Reduced sulfur compounds in gas from construction and demolition debris landfills. Waste Management 26, 526-533.

[4] Eun, S., Reinhart, D.R., Cooper, C.D., Townsend, T.G., Faour, A., 2007. Hydrogen sulfide flux measurements from construction and demolition debris (C\&D) landfills. Waste Management 27, 220-227.

[5] Xu, Q., Townsend, T., Reinhart, D., 2010. Attenuation of hydrogen sulfide at construction and demolition debris landfills using alternative cover materials. Waste Management 30(4), 660-666.
[6] Fang, J.J., Yang, N., Cen, D.Y., Shao, L.M., He, P.J., 2012. Odor compounds from different sources of landfill: Characterization and source identification. Waste Management $32,1401-1410$.

[7] López, A., Lobo, A., 2014. Emissions of C\&D refuse in landfills: A European case. Waste Management 34, 1446-1454.

[8] Yue, E., Han, B., Sun, Y., Yang, T., 2014. Sulfide emissions from different areas of a municipal solid waste landfill in China. Waste Management 34, 1041-1044.

[9] Townsend, T., Tolaymat, T., Leo, K., Jambeck, J., 2004. Heavy metals in recovered fines from construction and demolition debris recycling facilities in Florida. Science of the Total Environment 332, 1-11.

[10] Townsend, T., Jambeck, J., Jang, Y., Plaza, C., Xu, Q., Clark, C., 2005. C\&D Waste Landfill in Florida: Assessment of True Impact and Exploration of Innovative Control Techniques. Florida Center for Solid and Hazardous Waste Management, Gainesville, FL, USA.

[11] Jang, Y.C., Townsend, T., 2001. Sulfate leaching from recovered construction and demolition debris fines. Advances in Environmental Research 5(3), 203-217.

[12] Inoue, Y., 2005. Mechanism of strong hydrogen sulfide gas formation in inert industrial waste landfill sites and countermeasures. Research Report from the National Institute for Environmental Studies, Japan, 188.

[13] Masamoto, H., Matsukiyo, A., Shigematsu, M., Matsufuji, Y., Yanase, R., 2012. Suppression of Hydrogen Sulfide Release from Waste Plasterboard Disposal in a Landfill-type Lysimeter. Journal of the Japan Society of Waste Management Experts 23(3), 144-153. (in Japanese)

[14] Naruoka, T., Ono, Y., 2004. Control measures against hydrogen sulfide production in final landfill sites. Journal of National Environmental Research 29(4), 14-19. (in Japanese)

[15] Bergersen, O., Haarstad, K., 2014. Treating landfill gas hydrogen sulphide with mineral wool waste (MWW) and rod mill waste (RMW). Waste Management 34, 141-147.

[16] Adib, F., Bagreev, A., Bandosz, T.J., 1999. Effect of Surface Characteristics of Wood-Based Activated Carbons on Adsorption of Hydrogen Sulfide. Journal of Colloid and Interface Science 214(2), 407-415.

[17] Karge, H.G., Raskó, J., 1978. Hydrogen sulfide adsorption on faujasite-type zeolites with systematically varied $\mathrm{Si}$-Al ratios. Journal of Colloid and Interface Science 64(3), 522-532.

[18] Bentzen, G., Smit, A.T., Bennett, D., Webster, N.J., Reinholt, F., Sletholt, E., Hobsont, J., 1995. Controlled dosing of nitrate for prevention of $\mathrm{H}_{2} \mathrm{~S}$ in a sewer network and the effects on the subsequent treatment processes. Water Science and Technology 31(7), 293-302.

[19] Zhang, L., Schryver, P.D., Gusseme, B.D., Muynck, W.D., Boon, N., Verstraete, W., 2008. Chemical and biological technologies for hydrogen sulfide emission control in sewer systems: A review. Water Research 42, 1-12.

[20] Stumm, W., Morgan, J.J., 1996. Aquatic chemistry -Third Edition, John Wiley \& Sons, New York.

[21] Farrell, M., Jones, D.L., 2010. Food waste composting: Its use as a peat replacement. Waste Management 30, 1495-1501. 
274 Shumpei Kitazaki et al.: Hydrogen Sulfide Generation Suppression by Nitrate Addition - Application to Solid Waste Landfill Site

[22] Hasan, K.M.M., Sarkar, G., Alamgir, M., Bari, Q.H., Haedrich, G., 2010. Study on the quality and stability of compost through a Demo Compost Plant. Waste Management 32, 2046-2055.

[23] American Chemical Society, 2006. Reagent chemicals: specifications and procedures: American Chemical Society specifications, Oxford University Press. p. 242.

[24] Ono, Y., Tanaka, N., 2003. Preventing hazardous-level generation of hydrogen sulfide gas in landfill sites: Possibilities and administrative criteria. Journal of the Japan Society of Waste Management Experts 14(5), 248-257. (in Japanese)

[25] Garcia, C., Hernandez, T., Costa, F., Polo, A., 1991. Humic substances in composted sewage sludge. Waste Management and Research 9(1), 189-194.

[26] Hamamura, K., Shimizu, N., Tsuchida, D., Nagase, M., Toba, M., Kurokawa, Y., et al., 2009. A study of the dissolution behavior of chlorine from incinerator residue mixed with organic composts for cement raw material. Journal of the Japan Society of Waste Management Experts 20(1), 52-60. (in Japanese)

[27] Piccolo, A., Mbagwu, J.S.C., 1999. Role of hydrophobic components of soil organic matter in soil aggregate stability. Oil Science Society of America Journal 63(6), 1801-1810. 